\title{
An Incredible Mentor: a Tribute to Dick Bakemeier
}

\author{
Joseph O'Donnell ${ }^{1}$
}

Published online: 2 April 2016

(C) American Association for Cancer Education 2016

Our esteemed editor, Art Michalek, has written a beautiful piece above on the life, career, legacy, and impact of Dr Dick Bakemeier. My own reflections are much more personal about Dick and his impact on me. I have poured my heart out writing about Dick in the past..." on the shoulders of a giant" and "to be beloved"... and I had a hard time sitting down to write the finality that this last piece meant about Dick. I found that even though I have poured my heart out in the past that as I went back in there, my heart was still incredibly full, of both love and gratitude.

I entitled my last piece in the Journal's 25th anniversary tribute to Dick using a favorite a Raymond Carver poem I love named "Afterglow" [1]. I repeat the poem...it is worth your reading again!

\author{
And did you get what \\ you wanted from this life, even so? \\ I did. \\ And what did you want? \\ To call myself beloved, to feel myself \\ beloved on the earth.
}

\section{Dick was beloved.}

In previous writings, I have called him a giant [2] (on whose shoulders we all stand...so that we may see further), a mensch (those Yiddish words capture so much), and the father of cancer education (working in cahoots with Margaret Edwards, whom I consider the mother!). He was also the very proud father of this Journal. I have a new

Joseph O’Donnell

Joseph.F.ODonnell@Dartmouth.edu

1 Geisel School of Medicine at Dartmouth, Hanover, NH, USA moniker for him...he was also the Johnny Appleseed of cancer education, sewing his seeds and preparing the soil all over the globe. He, Margaret, and friends travelled all over this country to raise the bar for cancer education in every medical and dental school. His seminal work leading the two national surveys on the state of cancer education produced the mantra that it needed coordination in every school and every curriculum to be most effective. I participated on the second survey with him and the findings that the loss of coordination that the early r25 grants provided was having ill effects...cancer education was getting fragmented, siloed and less instead of more coordinated. He was the heart and soul of the American Association for Cancer education for years and along with colleagues from Europe like Millie Haagedorn, Wim Bender and others, he helped plant the seeds (or at least prepared the soil) that grew into the EACE.

I have been fortunate to have many mentors, but he was the most important mentor for me and so many others. He did so in person for so many, but his role in writing the orange book which weaned so many cancer careers had a huge impact for a whole generation of health professionals and his founding and labor of love growing this journal helped so many become "published," promoted, and valued. Countless students at Rochester and then Denver got a taste of cancer medicine though his summer research assistantships. To paraphrase what Robert Kennedy said in South Africa, Dick was like the person throwing pebbles into the pond, each producing ripples and those ripples united into a huge wave that would break down barriers for cancer education and cancer care.

His effects on me were very personal. I was complaining when my cancer center director sent me to Newark, NJ to attend my first AACE meeting, when my colleagues were going to meeting in Europe or what I thought were "cooler" venues in the USA, but little did I know that that assignment would prove to be the best thing that ever happened to me. 
AACE and Dick have had more to do with my professional formation than anything else.

He welcomed me generously into the AACE, later that year invited me to Rochester to work with a group on cancer educational objectives, promoted my growth in AACE to leadership positions, involved me in the second national cancer education survey, and groomed me to take over his beloved journal.

No one could outwork him. He always kept us on task when doing a project through his own example, and he was a stickler for "doing it right," getting the details, and process right and not taking short cuts. In my clinical career, every time I saw a patient, made an opinion at a tumor board, wrote a clinical note or wrote or reviewed an article, I felt the presence of Dick on my shoulder. The great thing that he did was be a perfect mentor and "supported, advised and challenged" me to always be my best [3]. He was an early adopter that the best care was multidisciplinary in nature, but from early on, he recognized the roles of other professions and was a force helping to foster interprofessional care as the gold standard for great care.

Dick himself was weaned in the Rochester way, a colleague of Morgan and Engel, and that Rochester group brought whole patient care to the forefront of medicine. They championed the bio-, psycho-, social, and spiritual model. Dick bought his own heartland values of midwest "nice" to that group, and his gentle, principled, and disciplined approach infected me and so many others to value the whole patient, respect colleagues from other professions and as he did at Cambridge, England as an oarsman himself, to row the boat together.

I will close with some words from the last lines of a poem by Mary Oliver called In Blackwater Woods [4]:

To live in this world

you must be able

to do three things:

to love what is mortal;

to hold it

against your bones knowing

your own life depends on it;

and, when the time comes to let it go,

to let it go.
I loved Dick and tried to hold him as close as possible even over the distance from New Hampshire to Colorado, and now I must try to let go, but that is so difficult.

These three things Oliver names are not easy, of course. Parker Palmer, the great guru of education, wrote about these three things in this poem - his key question about these seems simple enough on the surface: "What do I want to let go of and what do I want to hang onto?"

He found that that question did not work for him and did not open onto a path he wanted to walk. So he said, he took this quandary to a small group of trusted friends who sat with him for $2 \mathrm{~h}$. Their role was not to advise or "fix" him, but to ask honest, open questions and simply listen to the responses, giving him a chance to hear his own inner wisdom more clearly.

$\mathrm{He}$ said that he emerged from that little gathering with something more important than an answer. He emerged with a better question. He found himself no longer asking, "What do I want to let go of and what do I want to hang onto?" Instead he asked, "What do I want to let go of and what do I want to give myself to?"

I will let go of Dick's human presence... his always being there for me, my north star of sorts. Like he modeled, I will continue to give myself to his quest, spurred on by his example, to make this a better world and ease the suffering from cancer.

RIP, Dick...father of cancer education and the JCE, Johnny Appleseed of cancer education, great friend, colleague, and mentor. You have made this world a better place.

\section{References}

1. O'Donnell JF (2010) "To call myself beloved, to feel myself beloved on earth" - a tribute to our founding editor Dick Bakemeier, Journal of Cancer Education. Journal of Cancer Education 25:138-39

2. O'Donnell JF, The O (2005) Shoulders of a giant. Journal of Cancer Education 20(4):203-4

3. O’Donnell JF (1995) On mentoring. Journal of Cancer Education 10(3): 176

4. Oliver, Mary, At Blackwater Pond: Mary Oliver reads Mary Oliver, Audio CD, www.amazon.com 